\title{
DETERMINAN MODEL PILIHAN MODA TRANSPORTASI DI KAWASAN UNIVERSITAS PALANGKA RAYA
}

\author{
Abia Gustiano Delaperta Sutomo ${ }^{1}$, Sutan Parasian Silitonga ${ }^{2}$, Murniati $^{3}$ \\ ${ }^{123}$ Program Studi Teknik Sipil, Fakultas Teknik, Universitas Palangka Raya \\ E-mail: abiasutomo@gmail.com¹, sutan@jts.upr.ac.id², \\ murniati-upr@jts.upr.ac.id ${ }^{3}$
}

\begin{abstract}
ABSTRAK
Universitas Palangka Raya memulai gerakan peduli lingkungan dengan merencanakan $80 \%$ kampus hijau pada tahun 2034, salah satunya dalam bidang transportasi. Tujuan penelitian ini adalah untuk mengetahui faktor-faktor yang mempengaruhi pemilihan moda, memperoleh model pemilihan moda antara moda konvensional, sepeda elektrik dan bus elektrik di Kawasan Universitas Palangka Raya. Survai yang dilakukan adalah stated preference untuk membentuk model saat ini dan model simulasi dimasa mendatang. Pengolahan data dan analisis dilakukan untuk melihat kesesuaian model dengan melakukan uji statistik. Faktor yang secara statistik signifikan mempengaruhi variabel tetap adalah variabel jenis kelamin, jarak rumah ke UPR, waktu tempuh menggunakan sepeda motor, ketersediaan moda di rumah dan life style. Berdasarkan model yang terbentuk, peluang moda transportasi ramah lingkungan dapat ditingkatkan dengan menyediakan moda transportasi ramah lingkungan yang aman, nyaman, cepat, tepat waktu, serta kuantitas moda yang memenuhi kebutuhan transportasi seluruh sivitas akademika Universitas Palangka Raya.

Kata Kunci: pilihan moda, transportasi ramah lingkungan, multinomial logit, stated preference
\end{abstract}

\begin{abstract}
Palangka Raya University started a movement to care for the environment by planning $80 \%$ green campuses at 2034, one of which is in the field of transportation. The purpose of this study was to determine the factors that influence the choice of mode, to obtain a model of mode selection between conventional modes, electric bicycles and electric buses in the Palangka Raya University Area. The survey conducted is stated preference to form the current model and future simulation models. Data processing and analysis was carried out to see the suitability of the model by performing statistical tests. Factors that statistically significantly affect the fixed variables are the variables of Gender, Distance from Home to UPR, Motorcycle Travel Time, Availability of Modes at home and Life Style. Based on the model formed, the opportunity for environmentally green transportation modes can be increased by providing environmentally green transportation modes that are safe, comfortable, fast, on time, and with a quantity of modes that meet the transportation needs of the entire academic community.

Key word: mode choice model, green transportation, multinomial logit, stated preference
\end{abstract}




\section{PENDAHULUAN}

Seiring perkembangan zaman yang semakin maju mendorong manusia memanfaatkan sumber daya alam yang ada untuk meningkatkan produktifitas. Namun sumber daya alam terbatas, dan penggunaan secara masif berdampak buruk bagi lingkungan dan kehidupan generasi dimasa yang akan datang. Pembakaran bahan bakar fosil dari kendaraan bermotor menghasilkan emisi gas buang menjadi salah satu faktor yang memicu terjadinya pemanasan global. Universitas Palangka Raya (UPR), sebagai salah satu institusi pendidikan tinggi, dituntut untuk berperan aktif menghadapi tantangan global antara lain tentang era disrupsi, industri digital 4.0, dan juga isu-isu lingkungan sehingga memahami serta mengambil manfaat dengan memanfaatkan peluang-peluang baru yang tercipta akibat dari perubahan-perubahan tersebut. Dalam "Master Plan Konsep Pengembangan Universitas Palangka Raya 2018-2034" mencanangkan terwujudnya $80 \%$ green campus seperti pengembangan bangunan kampus, utilitas bangunan, pengembangan dan pemanfaatan energi, serta sistem jaringan transportasi umum yang ramah lingkungan. Salah satu cara mengetahui apakah moda transportasi ramah lingkungan dapat diterima oleh sivitas akademika Universitas Palangka Raya, maka penulis tertarik untuk menganalisis perencanaan pilihan moda transportasi ramah lingkungan di Universitas Palangka Raya. Tujuan penelitian ini adalah untuk mengetahui faktor-faktor yang mempengaruhi pemilihan moda dan model pemilihan moda di Universitas Palangka Raya.

\section{METODE PENELITIAN}

\section{Lokasi dan Waktu Penelitian}

Penelitian ini dilakukan di Universitas Palangka Raya, Kelurahan Palangka, Kecamatan Jekan Raya, Kota Palangka Raya, Kalimantan Tengah. Penelitian ini dilakukan pada bulan Januari tahun 2021.

\section{Metode Pengumpulan Data}

Data sekunder penelitian ini berupa jenis moda dan peta rencana rute moda transportasi yang diperoleh dari Master Plan Pengembangan Kampus Universitas Palangka Raya 2018-2034. Jumlah sivitas akademika Universitas Palangka Raya berjumlah 18.837 orang, yang terdiri dari 767 dosen, 17.238 mahasiswa, dan 832 staf/pegawai diperoleh dari Pangkalan Data Pendidikan Tinggi (PDDikti) tahun 2021. Data primer penelitian dalam ini adalah hasil kuisioner yang diisi oleh responden (sivitas akademika Universitas Palangka Raya) melalui google formulir. Jumlah sampel data sebanyak 342 sampel ditentukan menggunakan metode sampling yang dikembangkan oleh Isaac dan Michael dengan tingkat kesalahan 5\% untuk populasi sebanyak 18.837 orang.

\section{Tahapan Pengolahan Model}

Tahapan pemodelan yang dilakukan dalam penelitian dimulai dari identifikasi variabel yang memungkinkan memberi pengaruh signifikan terhadap alternatif pilihan moda, 
JURNAL KACAPURI

JURNAL KEILMUAN TEKNIK SIPIL

Volume 4 Nomor 2 Edisi Desember 2021

dilanjutkan dengan memodelkan utilitas pelaku perjalanan, dan memodelkan peluang alternatif pilihan moda.

\section{Menentukan Variabel Penelitian}

a. Variabel bebas (Independent Variabel)

1. Jenis Kelamin (X1), diamati sebagai variabel dummy yaitu (0) perempuan sebagai base category dan (1) laki-laki.

2. Usia (X2), usia diamati dengan skala ordinal yaitu (1) < 20 tahun, (2) 20-30 tahun, dan (3) > 30 tahun.

3. Pendapatan Keluarga (X3), data pendapatan keluarga juga dapat didekati dengan memvariasikan data secara langsung dan tidak langsung melalui korelasi kepemilikan atribut social (areal tempat tinggal, kepemilikan moda dan jenis pekerjaan). Variasi pada penelitian ini yaitu (1) $<5$ juta rupiah, (2) 6-15 juta rupiah, dan (3) $>15$ juta rupiah.

4. Moda Sehari-hari (X4), untuk mengetahui apakah ada hubungan antara moda sehari-hari dengan moda yang akan dipilih. Variabel ini memiliki pilihan (0) Sepeda Motor dan (1) Mobil.

5. Jarak Rumah ke UPR (X5), panjang perhitungan diperhitungkan responden melakukan perjalanan dalam kota aja, yaitu (1) $<1 \mathrm{~km}$, (2) $1-5 \mathrm{~km}$, (3) $5-10 \mathrm{~km}$, dan (4) $>10 \mathrm{~km}$.

6. Waktu Tempuh Motor (X6), diamati dengan skala ordinal waktu yang diperlukan saat menggunakan sepeda motor menuju Universitas Palangka Raya dengan ketentuan (1) < 5 menit, (2) 6-10 menit, (3) 10-15 menit dan (4) > 15 menit

7. Waktu Tempuh Mobil (X7), diamati dengan skala ordinal waktu yang diperlukan saat menggunakan mobil menuju Universitas Palangka Raya dengan ketentuan (1) < 5 menit, (2) 6-10 menit, (3) 10-15 menit dan (4) > 15 menit

8. Biaya Relatif Rumah ke UPR (X8), data variabel ini diamati berdasarkan estimasi responden terhadap biaya single trip, dengan jenis data skala ordinal, antara lain (1) < 5 ribu rupiah, (2) 5-10 ribu rupiah, dan (3) > 10 ribu rupiah

9. Ketersediaan Moda (X9), ketersediaan moda diamati sebagai rasio moda yang dapat digunakan secara penuh. Pada variabel ini ada pilihan (0) Tidak selalu ada dan (1) Selalu ada

10. Life Style (X10), yang diamati pada variabel ini adalah ada atau tidaknya pengaruh ketertatikan emosional pribadi terhadap pemilihan moda sebagai variabel dummy, yaitu pemilihan moda karana (0) Kebutuhan dan (1) Selera.

b. Variabel terikat (dependent variabel)

Jenis moda transportasi yang menjadi alternatif untuk digunakan dalam mobilisasi di kawasan Universitas Palangka Raya dimasa yang akan datang terdiri dari (1) Sepeda elektrik, (2) Bus elektrik dan (3) Tetap menggunakan moda konvensional. 
JURNAL KACAPURI

JURNAL KEILMUAN TEKNIK SIPIL

Volume 4 Nomor 2 Edisi Desember 2021

\section{Memodelkan Utilitas Pelaku Perjalanan}

Dalam penelitian ini digunakan Respon pilihan tunggal untuk model regresi logistik multinomial secara logis, setiap individu hanya memilih 1 alternatif moda untuk perjalanan alternatif lain hanya bersifat pembanding saja, dan tidak akan dipilih secara bersamaan.

Persamaan fungsi utilitas dapat dinyatakan sebagai berikut :

$U=f(X 1, X 2, X 3 \ldots \ldots . . V n)$

Dimana $U$ adalah utilitas pelaku perjalanan menggunakan moda, $X 1, X 2, X n$ adalah variabel-variabel bebas yang memiliki berpengaruh terhadap variabel terikat, $\operatorname{dan} f$ adalah hubungan fungsional utilitas

\section{Memodelan Peluang Alternatif Pilihan Moda}

Model peluang untuk 3 pilihan moda antara sepeda elektrik, bus elektrik, dan moda konvensional adalah sebagai berikut.

$P_{E-B i k e}=\frac{e^{Z e-b i k e}}{1+e^{Z e-b u s}+e^{Z e-b i k e}}$.
$P_{E-B u s}=\frac{e^{Z e-b u s}}{1+e^{Z e-b u s}+e^{Z e-b i k e}}$.
$P_{\text {Konv }}=\frac{1}{1+e^{Z e-b u s}+e^{Z e-b i k e}} \ldots .$.

Dimana $P_{E-\text { Bike }}$ adalah Peluang pemilihan Sepeda Elektrik, $P_{E-B u s}$ adalah Peluang pemilihan Bus Elektrik, dan $P_{K o n v}$ adalah Peluang pemilihan Moda Konvensional.

\section{HASIL \& PEMBAHASAN}

Hasil survai dari 342 responden, sebanyak 119 responden $(34,8 \%)$ memilih moda Sepeda Elektrik, 133 responden (38,9\%) memilih moda Bus Elektrik, dan 90 responden (26,3\%) memilih tetap menggunakan moda transportasi konvensional. Estimasi parameter fungsi utilitas untuk model logit dengan angkutan umum sebagai kategori refrensinya adalah sebagai berikut.

$$
\begin{aligned}
& U_{E-\text { Bike }}=12,75515+1,59352(J K)-3,346444(J R K)-1,29085(W M R)- \\
& 4.32894(K T M)-2,17535(L S) \\
& U_{E-B u s}=11,48821-0,97193(J K)-2,25547(J R K)-0,56073(W M R)- \\
& 3,91243(K T M)-3,07412(L S)
\end{aligned}
$$


JURNAL KACAPURI

JURNAL KEILMUAN TEKNIK SIPIL

Volume 4 Nomor 2 Edisi Desember 2021

Dimana, JK adalah Jenis Kelamin, JRK adalah Jarak Rumah ke UPR, WMR adalah Waktu Tempuh menggunakan Sepeda Motor, KTM adalah Ketersediaan Moda, dan LS adalah Life Style.

Fungsi utilitas diatas membentuk model pilihan moda antara e-bike, e-bus, dan moda konvensional sebagai berikut:

$$
\begin{aligned}
& \{12,75515+1,59352(\mathrm{JK})
\end{aligned}
$$

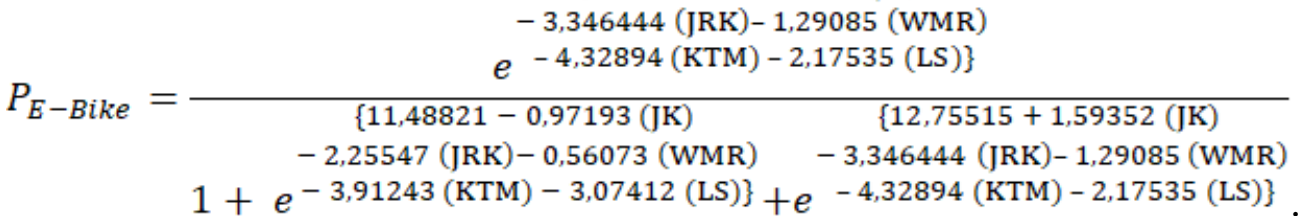

$$
P_{E-\text { Bus }}=\frac{\begin{array}{c}
\{11,48821-0,97193(\mathrm{JK}) \\
-2,25547(\mathrm{JRK})-0,56073(\mathrm{WMR})
\end{array}}{e^{-3,91243(\mathrm{KTM})-3,07412(\mathrm{LS})\}}}
$$

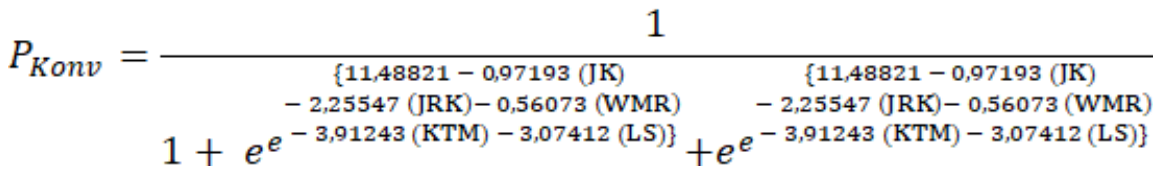

Dari model peluang yang terbentuk menunjukkan beberapa hal, antara lain:

1. Laki-laki memiliki peluang lebih tinggi menggunakan sepeda elektrik jika dibandingkan moda konvensional, sedangkan perempuan memiliki peluang lebih besar menggunakan moda konvensional dibandingkan bus elektrik.

2. Jika jarak rumah lebih jauh dari UPR maka peluang responden untuk memilih menggunakan moda konvensional lebih tinggi dibandingkan sepeda elektrik dan bus elektrik.

3. Jika waktu tempuh menggunakan sepeda motor dari rumah responden ke UPR semakin lama, maka peluang penggunaan moda konvensional berpeluang lebih tinggi dibandingkan sepeda elektrik dan bus elektrik.

4. Jika ketersediaan moda transportasi di rumah sivitas akademika selalu ada, maka peluang responden tetap memilih menggunakan moda konvensional lebih tinggi dibandingkan menggunakan sepeda elektrik dan bus elektrik.

5. Responden memiliki kecenderungan menggunakan moda konvensional apabila pemilihan dilakukan berdasarkan selera atau ketertarikan pribadi, dan apabila pemilihan moda didasarkan pada kebutuhan transportasi, maka responden cenderung menggunakan sepeda elektrik atau bus elektrik.

\section{PENUTUP}


JURNAL KACAPURI

Beberapa hal terkait dengan pemilihan moda antara sepeda elektrik, bus elektrik, dan moda konvensional di Universitas Palangka Raya untuk masa yang akan datang, antara lain sebagai berikut:

1. Variabel yang bernilai signifikan dan dapat mempengaruhi pilihan responden terhadap pilihan moda adalah Jenis Kelamin (X1), Jarak Rumah ke UPR (X5), Waktu Tempuh Motor (X6), Ketersediaan Moda (X9) dan Life Style (X10).

2. Model pilihan moda dari 342 responden pada alternatif moda yang ditawarkan antara sepeda elektrik, bus elektrik, dan moda konvensional membentuk probabilitas terpilihnya moda transportasi yaitu, $\mathrm{P}_{\text {Sepeda elektrik }}=26,61 \%, \mathrm{P}_{\text {Bus elektrik }}=$ $36,55 \%$, dan $\mathrm{P}_{\text {Moda Konvensional }}=36,84 \%$.

\section{DAFTAR PUSTAKA}

de Dios Ortúzar, J., \& Willumsen, L. G. (2011). Modelling transport. John wiley \& sons.

Miro, F. (2005). Perencanaan transportasi untuk Mahasiswa, Perencana dan Praktisi. Erlangga, Jakarta.

Morlok, E. K. (1991). Pengantar Teknik dan Perencanaan Transportasi, hlm. 451483. Jakarta: Penerbit Erlangga.

Pearmain, D., \& Kroes, E. P. (1990). Stated preference techniques: a guide to practice.

Tamin, O. Z. (2000). Perencanaan dan pemodelan transportasi. Penerbit ITB. 